\title{
Hubungan antara Status Nutrisi dengan Derajat Keparahan Pneumonia pada Pasien Anak di RSUP Sanglah
}

\author{
Artawan, Putu Siadi Purniti, I. G. Lanang Sidiartha \\ Bagian Ilmu Kesehatan Anak Fakultas Kedokteran Universitas Udayana/Rumah Sakit Sanglah, Denpasar
}

Latar belakang. Pneumonia masih menjadi masalah kesehatan global, khususnya di negara berkembang. Morbiditas dan mortalitas akibat pneumonia cukup tinggi pada anak berusia di bawah 5 tahun.

Tujuan. Mencari hubungan status gizi dengan derajat keparahan pasein pneumonia anak yang dirawat di RSUP Sanglah

Metode. Penelitian cross sectional yang dilakukan di Sub-Bagian Respirologi Bagian/ SMF Ilmu Kesehatan Anak FK UNUD/ RSUP Sanglah pada bulan Januari sampai dengan Desember 2014

Hasil. Total subyek adalah 114 dengan laki-laki lebih banyak dibanding perempuan $(58,8 \%$ vs $41,2 \%)$. Usia yang paling sering $0-6$ bulan $35,1 \%$ dengan status nutrisi baik $56,11 \%$, diagnosis yang paling banyak adalah pneumonia berat 76,3\%. Analisis bivariat menunjukan terdapat hubungan antara status gizi dengan derajat keparahan pneumonia, dengan nilai $\mathrm{p}=0,02$ dan PR IK95\% 2,176 $(1,094 \mathrm{~s} / \mathrm{d} 4,329)$.

Kesimpulan. Terdapat hubungan antara status gizi dengan derajat keparahan pneumonia pada anak. Sari Pediatri 2016;17(6):418-22.

Kata kunci: pneumonia, malnutrisi, anak

\section{The Relationship between Nutritional Status with Pneumonia Severity in Children at Sanglah Hospital, Bali, Indonesia}

Artawan, Putu Siadi Purniti, I G Lanang Sidiartha

Background. Pneumonia still a serious problem in medicine. Mortality and morbidity due to pneumonia are still very high, especially among children under 5 years.

Objective. To determine the relathionship between nutritional status with severity of pneumonia among pediatric patients at Sanglah general hospital.

Methods. The study was a cross sectional study done at Respirology division of Department of Pediatric, Faculty of Medicine/Sanglah hospital from January until December 2014.

Results. Total sample were 114 patients. Male subjects were more than female (58.8\% vs 41.2\%). most subjects were belong to 0-6 months old age group $35.1 \%$, with good nutritional status $56.11 \%$ and severe pneumonia $76.3 \%$. The bivariate analysis showed relationship between those two variables with p value 0.02 and PR 95\% CI 2.176 (1.094 to 4.329).

Conclusion. This study concluded that nutritional status was related to severity of pneumonia in children.

Sari Pediatri 2016;17(6):418-22.

Keywords: pneumonia, malnutrition, pediatric Alamat korespondensi: Dr. Artawan. Departemen Ilmu Kesehatan Anak Fakultas Kedokteran Universitas Udayana/Rumah Sakit Umum Pusat San-
glah, Denpasar. Jl. Diponegoro, Denpasar, Bali (80114), Indonesia, Tel. +62 82154000054. E-mail: artawanpediatri@yahoo.com 
S ampai saat ini, pneumonia masih menjadi masalah kesehatan global, khususnya di negara berkembang. Angka morbiditas dan mortalitas pneumonia cukup tinggi pada anak usia di bawah 5 tahun. Pada tahun 2007, tercatat 9,2 juta anak meninggal selama1 tahun di seluruh dunia, $92 \%$ dari total kasus ditemukan di benua Asia dan Afrika. Khusus di Afrika, angka kematian akibat pneumonia adalah 175 per 1000 kelahiran. Pakistan, India, Bangladesh, Tiongkok, Indonesia, dan Nigeria adalah negara dengan insiden pneumonia tertinggi di dunia. Jika dibandingkan dengan negara maju, seperti Amerika Serikat, angka ini sangat jauh berbeda. Di Amerika Serikat, jumlah kasus kematian akibat pneumonia dalam 1 tahun berjumlah antara 40.000-70.000 orang. ${ }^{1-5}$

Pneumonia didefiniskan sebagai peradangan pada parenkim paru yang disebabkan karena adanya proses infeksi oleh mikroorganisme (virus/bakteri). Selain infeksi pneumonia juga bisa disebabkan oleh aspirasi, radiasi, dan lain-lain. Bakteri merupakan penyebab utama pneumonia di negara berkembang, sedangkan virus lebih umum dijumpai di negara maju. Streptococcus pneumoniae dan Haemophilus influenzae merupakan bakteri terbanyak dijumpai. Pada tahun 2000 diperkirakan 13,8 juta kasus pneumonia dengan 741.000 di antaranya meninggal dunia akibat bakteri Streptococcus pneumoniae. ${ }^{2,6-9}$

Di Indonesia, jumlah kasus pneumonia mengalami peningkatan dari tahun ke tahun. Di RSUD dr. Soetomo pada tahun 2003, 2004, dan 2005 berturutturut terdapat 190, 231, dan 574 pasien pneumonia yang memerlukan rawat inap. ${ }^{10}$ Sementara itu pada tahun 2008, RSUP Sanglah melaporkan 156 pasien yang dirawat inap dengan pneumonia. ${ }^{11}$

Pneumonia menurut sumber penyebabnya dibagi menjadi dua macam, yaitu pneumonia masyarakat (community acquired pneumonia=CAP) dan pneumonia nosokomial (nosocomial pneumonia). Pada kasus CAP terdapat sejumlah faktor risiko yang berhubungan dengan pneumonia, khususnya di negara berkembang, seperti sosial ekonomi yang rendah, kepadatan penduduk yang tinggi, pemberian ASI non ekslusif, malnutrisi, BBLR, usia ibu saat menikah, tingkat pendidikan yang rendah, dan kebiasan merokok pada orangtua. ${ }^{1,2,4,5,7}$

Penelitian yang menghubungkan status gizi dengan derajat keparahan pneumonia pada anak pernah diteliti oleh Arpitha $\mathrm{dkk}^{17}$ di rumah sakit umum Mamata, India. Pada penelitiannya didapatkan hubungan yang bermakna antara kedua variabel tersebut. Di Indonesia, belum ada penelitian yang mencari hubungan antara status gizi dengan derajat keparahan pneumonia, sehingga penelitian ini dilakukan untuk mencari hubungan antara kedua variabel tersebut.

\section{Metode}

Penelitian cross sectionalyang dilakukan di Sub-Bagian Respirologi Bagian/ SMF Ilmu Kesehatan Anak FK UNUD/RSUP Sanglah pada bulan Januari sampai dengan Desember 2014. Kriteria inklusi adalah pasien rawat inap di ruang rawat anak RSUP Sanglah Denpasar dengan diagnosis akhir pneumonia berat serta pneumonia sangat berat, pada bulan Januari sampai dengan Desember 2014. Kriteria eksklusi adalah pasien dengan data yang tidak lengkap.

Sampel dikumpulkan dari rekam medis dan register. Berdasarkan data yang ada kemudian diaplikasikan pada rumus dan dibutuhkan sampel minimal 50 sampel. Data dasar subjek penelitian, yaitu usia, jenis kelamin, status gizi, diagnosis, diperoleh dari rekam medis dan disesuaikan dengan kuesioner yang terlampir. Data deskriptif yang diperoleh, disajikan dalam bentuk narasi dan tabel. Hubungan antar variabel dianalisis dengan metode analisis chi square dengan interval kepercayaan 95\%. Analisis dilakukan dengan menggunakan perangkat lunak SPSS 17,0. Penelitian telah mendapatkan persetujuan etik dari Komite Etik Penelitian Kesehatan Fakultas Kedokteran Universitas Udayana RSUP Sanglah Denpasar dengan nomor: 1142/UN.14.2/Litbang/2015.

\section{Hasil}

Berdasarkan data dari rekam medik pasien anak dengan diagnosis pneumonia tahun 2014, didapatkan total 114 pasien. Karakteristik subyek tertera pada Tabel 1.

Analisis bivariat dilakukan untuk mengetahui hubungan antara status gizi dan derajat pneumonia. Analisis statistik dengan chi-square tertera pada Tabel 2.

\section{Pembahasan}

Pneumonia merupakan penyakit yang disebabkan oleh infeksi pada parenkim paru. Diperkirakan sekitar 150,7 juta kasus pneumonia ditemukan setiap 
Artawan dkk: Hubungan antara status nutrisi dengan derajat keparahan pneumonia

Tabel 1. Karakteristik subyek $(\mathrm{n}=114)$

\begin{tabular}{lc}
\hline Variabel & Jumlah $(\%)$ \\
\hline Jenis kelamin & \\
Laki-laki & $67(58,8)$ \\
Usia & \\
$0-6$ bulan & $40(35,1)$ \\
$7-12$ bulan & $32(28,1)$ \\
1-5 tahun & $31(27,2)$ \\
$5-10$ tahun & $8(7,0)$ \\
$>10$ tahun & $3(2,6)$ \\
Status gizi & \\
Malnutrisi & $50(43,9)$ \\
Gizi baik & $64(56,15)$ \\
Derajat pneumonia & \\
Berat & $87(76,3)$ \\
Sangat berat & $27(23,7)$ \\
\hline
\end{tabular}

Tabel 2. Hubungan antara status gizi dengan derajat keparahan pneumonia

\begin{tabular}{|c|c|c|c|c|}
\hline \multirow[t]{2}{*}{ Status gizi } & \multicolumn{2}{|c|}{ Derajat pneumonia } & \multirow[b]{2}{*}{ RP (IK95\%) } & \multirow[b]{2}{*}{$\mathrm{p}$} \\
\hline & $\begin{array}{c}\text { Sangat berat } \\
\mathrm{n}(\%)\end{array}$ & $\begin{array}{l}\text { Berat } \\
\mathrm{n}(\%)\end{array}$ & & \\
\hline Malnutrisi & $17(62,9)$ & $33(37,9)$ & 2,176 & 0,02 \\
\hline Gizi baik & $10(37,1)$ & $54(62,1)$ & $(1,094 \mathrm{~s} / \mathrm{d} 4,329)$ & \\
\hline
\end{tabular}

IK: Interval kepercayaan; $\mathrm{p}=$ probabilitas; $\mathrm{RP}=$ rasio prevalens

tahunnya pada anak usia di bawah 5 tahun, 20 juta di antaranya memerlukan rawat inap. Di Eropa dan Amerika Utara, insiden pneumonia adalah 34-40 kasus per 1000 pada kelompok usia yang sama, tetapi pada kelompok remaja (12-15 tahun) ditemukan menurun jumlahnya 7 kasus per $1000 .{ }^{12}$ Pneumonia menyebabkan $18 \%$ kasus kematian pada anak di bawah usia 5 tahun, jumlah yang lebih banyak ditemukan di negara berkembang dibandingkan dengan negara maju $(20 \%$ vs $4,3 \%) .^{2,13}$

Pneumonia pada anak lebih sering ditemukan di negara berkembang. Terdapat 15 negara yang berkontribusi pada $74 \%$ kasus baru pneumonia dan lebih dari $50 \%$ di antaranya ditemukan pada 6 negara, yaitu Indonesia, India, Pakistan, Bangladesh, Tiongkok, dan Nigeria. Di Indonesia pada tahun 2008 dan 2009 insiden pneumonia anak di bawah 5 tahun mengalami peningkatan $49,54 \%$ dan 49,23 , tetapi pada tahun 2010 menurun menjadi 39,38\%.,

Kami mendapatkan total 114 pasien, sebagian besar berjenis kelamin laki-laki $(58,8 \%)$ dengan rentang usia
0-6 bulan $(35,1 \%)$. Ngozi $\mathrm{dkk}^{13}$ melaporkan bahwa pasien anak dengan pneumonia sebagian besar berjenis kelamin laki-laki (57\%) dan berusia 0-5 tahun (69\%). Penelitian lainnya oleh Kurniawan dan Indriani ${ }^{14}$ melaporkan 53,3\% pasien laki-laki dan 48,5\% berusia 0-1 tahun dari total 245 pasien dengan pneumonia. Hasil yang sama juga dilaporkan oleh Nataprawira $\mathrm{dkk}^{15}$ yang melaporkan $50 \%$ pasien laki-laki dan $69 \%$ berusia kurang dari 1 tahun.

Pneumonia dapat disebabkan oleh berbagai jenis mikroorganisme (virus/bakteri). Di negara berkembang pneumonia lebih sering disebabkan oleh bakteri, sedangkan di negara maju lebih sering desebabkan oleh virus. Bakteri yang bisa menyebabkan pneumonia di antaranya Streptococcus pneumoniae, Haemophilus influenza, dan Staphylococcus aureus. Virus yang bisa menyebabkan pneumonia di antaranya Respiratory syncitial, Influenza, dan Parainfluenza. Virus ini biasanya ditularkan melalui droplet ketika pasien batuk atau bersin. Pneumonia memiliki beberapa gejala, seperti sesak napas, demam, batuk, nafsu makan 
berkurang, dan mengi. ${ }^{3,7}$ Namun, manifestasi klinis yang muncul dapat bervariasi pada setiap individu, seperti sakit kepala, nyeri perut, dan muntah kadang dapat ditemukan pada pasien pneumonia. ${ }^{6}$

Diagnosis pneumonia dapat ditentukan berdasarkan manifestasi klinis. Diagnosis pneumonia berdasarkan WHO dibagi menjadi bukan pneumonia, pneumonia (tidak berat), pneumonia berat dan pneumonia sangat berat. Pemeriksaan radiologi dilakukan untuk membedakan pneumonia dengan bronkiolitis pada anak dengan usia yang lebih muda. Infeksi saluran nafas bawah didefinisikan sebagai demam, gejala pernapasan akut, dan adanya infiltrat parenkimal pada pemeriksaan radiologi. ${ }^{16}$

Pada penelitian kami, diagnosis pneumonia dibagi menjadi dua, yaitu pneumonia berat dan sangat berat. Delapanpuluh tujuh $(76,3 \%)$ pasien terdiagnosis sebagai pneumonia berat. Kurniawan dan Indriyani ${ }^{14}$ melaporkan $174(71 \%)$ pasien dengan diagnosis pneumonia berat dan $8(3,3 \%)$ dengan pneumonia sangat berat. Forsberg dkk $\mathrm{dk}^{6}$ melaporkan $35,7 \%$ pasien dengan pneumonia berat dan $25 \%$ dengan pneumonia sangat berat.

Faktor risiko yang berhubungan dengan pneumonia dibagi menjadi faktor instrinsik dan ekstrinsik. Faktor instrinsk meliputi jenis kelamin, umur, berat badan lahir rendah (BBLR), status gizi, pemberian vitamin A, pemberian air susu ibu (ASI), dan status imunisasi. Faktor ekstrinsik meliputi polusi udara, ventilasi, paparan asap rokok, kepadatan tempat tinggal, dan penggunaan bahan bakar. Di negara berkembang, faktor risiko pneumonia di antaranya status ekonomi rendah, berat badan lahir rendah, malnutrisi, pemberian ASI non eksklusif, defisiensi vitamin $\mathrm{A}$, kebiasaan merokok pada orang tua, polusi udara, defisiensi zinc, usia ibu, tingkat pendidikan ibu, pengalaman ibu sebagai pengasuh, ketinggian, dan kelembaban. ${ }^{1}$

Malnutrisi merupakan salah satu faktor risiko yang menyebabkan 53\% mortalitas penyakit infeksi pada anak di bawah 5 tahun di negara berkembang pertahunnya. Pneumonia pada anak dengan malnutrisi berat dilaporkan memiliki mortalitas yang tinggi. ${ }^{17}$ Escherichia coli, Staphylococcus aureus, dan Klebsiella pneumoniae adalah kuman patogen yang ditemukan pada pasien pneumonia dengan malnutrisi berbeda dengan mereka yang tanpa malnutrisi. ${ }^{4}$

Hubungan antara malnutrisi dan infeksi pernafasan akut pada anak telah beberapa kali diteliti di negara berkembang, dan menunjukkan hasil yang konsisten dan bermakna. Di Fortaleza dan Brazil dilaporkan anak dengan malnutrisi sedang dan berat memiliki kecenderungan untuk mengalami pneumonia 4,6 kali lebih besar. Angka mortalitas pada penelitian yang ada menunjukkan bahwa anak dengan malnutrisi berat memiliki risiko mortalitas 25 kali lebih tinggi akibat pneumonia. $^{18}$

Penelitian kami difokuskan pada malnutrisi sebagai faktor risiko pneumonia pada anak. Kami mendapatkan $50(43,9 \%)$ pasien pneumonia dengan malnutrisi dan $64(56,1 \%)$ tanpa malnutrisi. Monita $\mathrm{dkk}^{16}$ meneliti variasi status gizi pasien. Penelitian tersebut membagi status gizi menjadi 4 kategori, yaitu tanpa malnutrisi, malnutrisi ringan, malnutrisi sedang, dan malnutrisi berat. Kategori yang memiliki persentase terbanyak adalah tanpa malnutrisi dengan 52 (46\%) pasien, malnutrisi sedang 27 (23\%), malnutrisi ringan 24 (20\%), dan malnutrisi berat 13 (11\%) pasien.

Hubungan yang kuat dan konsisten telah banyak dilaporkan antara malnutrisi dengan kejadian mortalitas pada kasus infeksi saluran pernafasan. Pasien dengan malnutrisi mengalami masalah pada sistem imunitas, khususnya IgA. Malnutrisi menyebabkan terjadi penurunan level IgA, IgA pada sistem imun berfungsi untuk melindungi saluran nafas atas dari infeksi organisme patogenik. Oleh karena itu, penurunan level IgA mengakibatkan penurunan sistem imun saluran nafas sehingga akan memperparah derajat infeksi sistem saluran nafas. ${ }^{19}$

Berdasarkan analisis bivariat, terdapat hubungan antara status gizi dan derajat keparahan pneumonia. Pada penelitian kami, malnutrisi memiliki risiko 2,176 kali lebih besar menyebabkan derajat pneumonia lebih berat. Penelitian lainnya oleh Arpitha dkk ${ }^{17}$ melaporkan insiden pneumonia meningkat seiring makin buruknya derajat malnutrisi. Insiden pneumonia pada malnutrisi derajat I adalah 35,5\%, sedangkan pada derajat IV adalah $72 \%$. Hasil penelitiannya menunjukkan bahwa jumlah pasien dengan malnutrisi bermakna lebih banyak mengalami pneumonia (30\%) dibandingkan dengan pasien yang tanpa malnutrisi (9\%). Hartati ${ }^{20}$ melaporkan sebuah hubungan antara status gizi dengan insiden pneumonia. Hasil penelitiannya dengan analisis bivariat menunjukkan adanya hubungan yang bermakna antara status gizi dengan pneumonia. Pasien yang malnutrisi 6,52 kali lebih rentan untuk mengalami pneumonia dibandingkan dengan mereka yang dengan status gizi baik. 
Penelitian kami memiliki beberapa keterbatasan, yaitu patogen penyebab pneumonia tidak diidentifikasi, pasien ditangani oleh beberapa dokter yang berbeda dari sejak awal masuk rumah sakit yang berimplikasi pada keakuratan diagnosis, riwayat penggunaan antibiotik sebelumnya tidak diidentifikasi, dan jumlah sampel tidak cukup besar yang dapat memengaruhi hasil penelitian.

\section{Kesimpulan}

Disimpulkan bahwa status gizi berhubungan dengan derajat keparahan pneumonia pada anak. Penelitian selanjutnya sangat diperlukan untuk mengkonfirmasi hasil ini.

\section{Daftar pustaka}

1. Fekadu GA, Terefe MW, Alemia GA. Prevalence of pneumonia among under-five children in Este town and the surrounding rural Kebeles, Northwest Ethiopia; a community based cross sectional study. Sci J Pub Health 2014;3:150-5.

2. Gray D, Zar HJ. Childhood pneumonia in low and middle income countries: burden, prevention and management. Infect Dis J 2010;4:74-84.

3. Sulfahani SF, Razali SNA, Mormin MF, Khamis A. An analysis of the prevalence of pneumonia for children under 12 year old in Tawau general hospital, Malaysia. Research; 2012.h.1-8.

4. Ghimire M, Bhattacharya SK, Narain JP. Pneumonia in South-East Asia region: public health perspective. Indian J Med Res 2012;459-68.

5. Mokoginta D, Arsin A, Sidik D. Faktor risiko kejadian pnemonia pada anak balita di wilayah kerja puskesmas Sudiang kota Makassar. Makassar: Bagian Epidemiologi Fakultas Kesehatan Masyarakat. Universitas Hasanuddin,2014.

6. Forsberg P. Pneumonia among hospitalized children aged 1-9 years - a prospective and retrospective study at a referral hospital in northern Tanzania. Diakses pada 12 Maret 2016. Didapat dari:http://medicine.gu.se/
digitalAssets/1414/1414421_peter-forsberg-vt12.pdf.

7. Said M. Pneumonia. Dalam: Rahajoe NN, Supriyatno B, Setyanto DB, penyunting. Buku Ajar Respirologi Anak. Edisi ke-1. Jakarta: BP IDAI; 2012.h.350-65.

8. Don M. Pediatric community-acquired pneumonia. [Dissertation]: Case Tampere University;2009.

9. Singh YD. Pathophysiology of community acquired pneumonia. Supplement to Japi 2012;60:7-9.

10. Setyoningrum RA, Landia S, Makmuri MS. Pneumonia. Continuing Education XXXVI. 2006.

11. Subanada IB, Puniti NPS. Faktor-faktor yang berhubungan dengan pneumonia bakteri pada anak. Sari Pediatri 2010;12:184-9.

12. Eslamy HK, Newman B. Pneumonia in normal and immunocompromised children: an overview and update. Radiol Clin N Am 2011:895-920.

13. Ngozi N, Chidinma O, Martin N. A correlation between clinical and chest radiographic diagnosis of pneumonia in Nigerian children. Adv. Biores 2011;2:18-21.

14. Kurniawan Y, Indriyani SAK. Karakteristik pasien pneumonia di ruang rawat inap anak rumah sakit umum provinsi Nusa Tenggara Barat. CDK 2012;196-7.

15. Nataprawira HM, Alwi EH, Adriani N. Faktor risiko morbiditas dan mortalitas pneumonia berat pada anak usia balita. Maj Kedokt Indon 2010;60:443-7.

16. Monita O, Yani FF, Lestari Y. Profil pasien pneumonia komunitas di bagian anak RSUP DR. M. Djamil Padang Sumatera Barat. Jurnal Kesehatan Andalas 2015;4:21826.

17. Arpitha G, Rehman MA, Ashwitha G. Effect of severity of malnutrition on pneumonia in childern aged $2 \mathrm{M}-5 \mathrm{Y}$ at a tertiary care center in Khammam, Andhra Pradesh: a clinical study. Sch J App Med Sci 2014;2:3199-203.

18. Ranganathan SC, Sonnappa S. Pneumonia and other respiratory infections. Pediatr Clin N Am 2009;56:13556.

19. Rodríguez L, Cervantes E, Ortiz R. Malnutrition and gastrointestinal and respiratory infections in children: a public health problem. Int J Environ Res Public Health 2011;8:1174-205.

20. Hartati S. Analisis faktor risiko yang berhubungan dengan kejadian pneumonia pada anak balita di RSUD Pasar Rebo Jakarta, tesis. Jakarta: Fakultas Kedokteran Universitas Indonesia, 2011. 